\title{
Artelogie
}

artelogie Recherche sur les arts, le patrimoine et la littérature de l'Amérique latine

$14 \mid 2019$

Sensibilités : Arts, littératures et patrimoine en Amérique latine

\section{"Cafetín de Buenos Aires", uma janela sobre a cidade moderna: solidão e melancolia na experiência do tango dos anos 1930 e 1940}

\section{Avelino Romero Pereira}

\section{OpenEdition}

\section{Journals}

Edição electrónica

URL: http://journals.openedition.org/artelogie/3817

DOI: 10.4000/artelogie.3817

ISSN: 2115-6395

Editora

Association ESCAL

\section{Refêrencia eletrónica}

Avelino Romero Pereira, " "Cafetín de Buenos Aires", uma janela sobre a cidade moderna: solidão e melancolia na experiência do tango dos anos 1930 e 1940 », Artelogie [Online], 14 | 2019, posto online no dia 07 janeiro 2019, consultado o 17 setembro 2019. URL : http://journals.openedition.org/ artelogie/3817 ; DOI : 10.4000/artelogie.3817

Este documento foi criado de forma automática no dia 17 Setembro 2019.

Association ESCAL 


\title{
"Cafetín de Buenos Aires", uma janela sobre a cidade moderna: solidão e melancolia na experiência do tango dos anos 1930 e 1940
}

\author{
Avelino Romero Pereira
}

\section{Cafetín de Buenos Aires}

\author{
De chiquilín te miraba de afuera \\ como a esas cosas que nunca se alcanzan; \\ la ñata contra el vidrio, \\ en un azul de frío, \\ que solo fue después, viviendo, \\ igual al mío... (ROMANO, 2007: 376)
}

1 Com esses versos, Enrique Santos Discépolo inicia Cafetín de Buenos Aires, tango escrito em 1948, em parceria com o pianista e compositor Mariano Mores, logo gravado na voz de Edmundo Rivero com o acompanhamento da orquestra de Aníbal Troilo. O poema, uma apologia aos cafés da cidade, rememora experiências da juventude e procura traduzir o acolhimento inspirado pelo ambiente fraternal desses mesmos cafés, tão presentes na vida cotidiana da cidade desde meados do século XIX. Qualificando-o "como una escuela de todas las cosas", Discépolo marca, na trajetória do protagonista de seu tango, essa presença constante do café como espaço privilegiado da sociabilidade do homem porteño:

Como una escuela de todas las cosas,

ya de muchacho me diste entre asombros:

el cigarrillo, la fe en mis sueños

y una esperanza de amor. (ROMANO, 2007: 376)

2 Considerando o papel dos cafés nas formas de ócio e sociabilidade desenvolvidas paralelamente ao processo de modernização por que passou a cidade de Buenos Aires entre 1880 e 1930, e citando justamente o tango de Discépolo, Oscar Troncoso o compara a um "tratado filosófico". Registra o autor que o café "fue el mayor consumidor de las horas 
de los porteños y el lugar donde más gastaron su tiempo libre" (TRONCOSO, 2000: 286). Mas o que se mostra com ênfase na descrição poética de Discépolo é a mirada melancólica que o tanguero lança sobre essa experiência do passado, tão marcante que o poeta compara o acolhimento do café à figura materna:

Cómo olvidarte en esta queja,

cafetín de Buenos Aires,

si sos lo único en la vida

que se pareció a mi vieja. (ROMANO, 2007: 376)

3 Ao assumir a própria melancolia como "queixa", Discépolo faz lembrar a descrição que Freud dá ao comportamento do tipo melancólico, por seu apego obstinado ao passado e pelas recriminações com que se situa desconfortavelmente na vida psíquica e social. ${ }^{1} \mathrm{O}$ sentido melancólico dos versos se completa na referência ao suicídio como opção diante da dor de estar no mundo e também no abandono de si mesmo, indicativo da perda da autoestima:

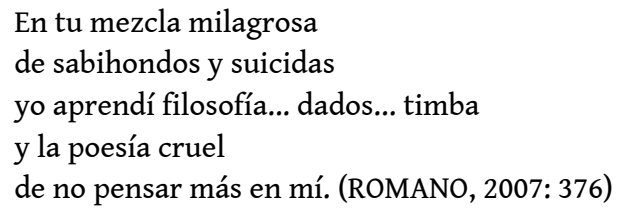

4 Sem pretender aprofundar aqui essas correlações entre tango e melancolia, já abordadas em outros trabalhos (PEREIRA, 2012b e 2014a), remeto o leitor às reflexões conduzidas por Ana Jaramillo em torno do tema. Para a autora, "esa idea fija del melancólico que el tango expresa, es un espacio existencial, temporal, sacralizado por el profano que no resiste la ansiedad ni la tensión de la relatividad y homogeneidad del Mundo" (JARAMILLO, 1995: 115). A melancolia no tango seria assim uma resposta a uma crise histórica, crise de valores, que leva o sujeito a se aferrar a um espaço existencial sacralizado, que o acolha em meio ao relativismo ético. Mas voltando aos versos de Discépolo, insisto ainda na temática da sociabilidade, que me permitirá outras considerações posteriores:

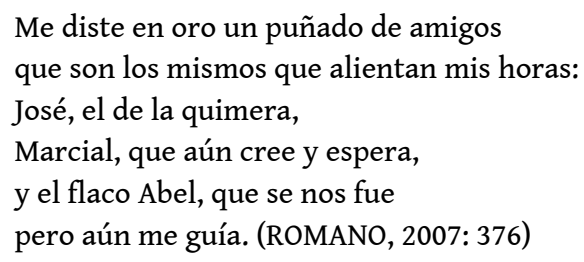

5 Sob esse tom confessional, Discépolo salienta o convite à amizade e à intimidade, nomeando amigos, provavelmente ficcionalizados, que tipificam um mesmo perfil psíquico, haurido em experiências sociais compartilhadas. Ao fazê-lo, aponta um traço muito presente nas construções discursivas em torno da identidade do homem porteño, que é o da amizade como marca de sociabilidade e inserção nos âmbitos coletivos, sobretudo masculinos. A demografia da grande imigração que impactou a sociedade argentina revela, por exemplo, que entre 1881 e 1914 apenas um terço dos imigrantes era constituído de mulheres e 55\% desses imigrantes tinham entre 13 e 30 anos, o que implica pensar uma Buenos Aires predominantemente masculina e jovem (CIBOTTI, 2000). Subentende-se daí que a condição imigratória pressupõe uma experiência fortemente ancorada na solidão, vindo a reforçar enormemente o papel dos laços de amizade. Nesse sentido, esses espaços públicos em que podiam desenvolver-se os contatos e as intimidades tornam-se verdadeiras ilhas de afetividade cercadas por estranheza e desenraizamento. De fato, para Sandra Gayol, espaços como os cafés eram "enclaves predominantemente masculinos" (GAYOL, 1993: 258) e, no dizer de José Luis Romero, "un 
café ofrecía compañía y solaz a los muchachones" (ROMERO, 2000a: 15). Comentando o impacto do projeto modernizador sobre a cidade e suas dinâmicas culturais, o historiador vê aí uma "sociedad inestable, puesto que se integraba al calor de los ascensos y descensos de clase, de los triunfos y las frustraciones" (Idem). ${ }^{2}$

6 As dores da experiência social vêm somar-se às existenciais, contribuindo para uma percepção desencantada do mundo, que termina internalizada nas letras dos tangos. Assim, casa-se o papel social às experiências individualizadas, e os cafés são representados como palcos públicos em que são encenadas as tragédias pessoais. Discépolo conclui então a letra de Cafetín de Buenos Aires, fazendo menção às penas de amor, ao álcool e, novamente, à situação de desânimo. Descreve então um estado de crise que o leva a reiterar o papel do café como espaço testemunhal da experiência vista e vivida:

Sobre tus mesas que nunca preguntan

lloré una tarde mi primer desengaño,

nací a las penas,

bebí a mis años,

y me entregué sin luchar. (ROMANO, 2007: 376)

7 Esse estado de crise agudamente descrito nessa última estrofe terminaria atraindo a censura do governo Perón sobre o tango de Discépolo, em 1949, pouco depois de sua estreia. Desde o golpe militar de 1930, o tango vinha sendo alvo de uma campanha de "depuração" movida sobretudo por intelectuais conservadores, militares nacionalistas e pela Igreja Católica, que visava a extirpar de suas letras os termos colhidos no lunfardo como "vieja" por mãe e "timba" por jogo, que aparecem nos versos de Cafetín de Buenos Aires. Além do purismo linguístico, também temas clássicos na poética tanguera, como a prostituição, o álcool, as drogas, o jogo, o crime, eram objetos da censura instalada no rádio em 1930 e reforçada pela nova ditadura militar empoderada em 1943. Embora Perón mantivesse boas relações com os tangueros e inclusive laços de amizade com Discépolo, os versos deste não escapariam do zelo da Secretaría de Prensa y Difusión, vinculada à presidência da república, que o acusou de haver escrito uma canção pessimista, marcada pela fórmula que a encerra: "y me entregué sin luchar". A condenação realçava a inadaptação dos versos ao tom festivo oficial da "Nueva Argentina" peronista, que aquele órgão de comunicação se encarregava de difundir. ${ }^{3}$

Dado o enorme prestígio de Discépolo no meio cultural de Buenos Aires, a proibição seria a gota d'água que levaria os tangueros, reunidos em torno da Sociedad Argentina de Autores y Compositores de Música (Sadaic), a reagirem, peticionando diretamente a Perón contra a censura que lhes obrigava a reescrever as letras, transformando velhos sucessos em versões insípidas. $O$ presidente recebeu então uma comissão de compositores e poetas e a censura arrefeceu, embora não chegasse a ser abolida por completo nem oficialmente, a não ser alguns anos depois, em 1953, quando uma lei de radiodifusão aprovada pelo legislativo deixaria de mencionar as restrições linguísticas. A reunião com Perón seria noticiada pelo jornal oficialista Noticias Gráficas, que tentava assim atenuar os efeitos da censura e ainda colher louros ao governante, apontando seu encenado apoio ao pleito dos artistas. Entrevistado, Discépolo faria a defesa de seus versos, dizendo que "hay cosas que sólo se puede decir de un modo. Cambien el tono y harán el ridículo, por demasiado solemnes, por excesivamente correctos" (citado por PUJOL, 2006: 355-356). Na sequência, respondeu à crítica de que teria escrito versos pessimistas: "pero yo no inventé 
la realidad que refleja”, e ainda provocou o censor: “¿Cómo me van a negar que muchos porteños sólo han tenido por mucho tiempo al café como meta de sus vidas?" (Idem).

9 Ao contrastar os anos peronistas com o passado, a que os tangos costumeiramente estavam aferrados, Discépolo marcava o que seu mais competente biógrafo chama de "estética del desencanto" (PUJOL, 2006), firmando assim um vínculo irrefutável entre o estilo poético de seus tangos e a percepção de uma crise mais profunda, que ultrapassa os estreitos limites cronológicos dados pela crise de 1929 e o golpe militar de 1930, que deram início à chamada "década infame". ${ }^{4}$ Essa percepção de uma crise mais ampla que a sugerida pelo tempo curto teria levado o poeta a escrever em 1934 os conhecidos versos de Cambalache, estreado no ano seguinte, reconhecendo "que el mundo fue y será una porquería", marcando porém a piora de todas as coisas nesse "siglo veinte cambalache, problemático e febril". A tradição interpretativa em torno do tango em geral e de Discépolo em particular salienta os vínculos entre sua poética desencantada e a situação social e política argentina dos anos 1930. O poeta, que na juventude partilhara dos ideais anarquistas e depois se aproximaria ao peronismo, é convertido assim num herói popular de uma resistência cultural entrincheirada no tango como forma de protesto contra os abusos cometidos pelos governos oligárquicos: a violência política e cultural, a corrupção, a fraude eleitoral, a dependência ao imperialismo britânico. Escrevendo nos anos 1960, Norberto Galasso dirá, por exemplo, que Cambalache "sintetiza el panorama social de la Argentina y del mundo en ese sombrío año 35" (GALASSO, 2004: 102). E agrega que "sus versos se constituyen en agudo testimonio de la descomposición del régimen oligárquico en nuestro país, al par que significan una descarnada acusación al mundo por la corrupción y decadencia" (Idem). Por sua vez, e de uma forma mais ampla, ao comentar a linguagem da crise no tango daqueles anos, Rosalba Campra (1996) dirá que:

El pesimismo vital de los treinta se cargó de un repertorio de metáforas, comparaciones, elecciones léxicas, que fueron canonizadas por los tangos posteriores y entraron a formar parte de un patrimonio colectivo. A esta herencia se recurre cada vez que se trata de expresar la percepción del mundo como espacio de una lucha desigual cuyo resultado está decidido de antemano, la aceptación del fracaso y quizá, esencialmente, el sufrimiento sin lucidez sobre las causas que lo motivan. (CAMPRA, 1996: 36)

10 Sem desmerecer o impacto negativo da experiência conjuntural marcada pelas vicissitudes dos anos 1930, mas levando em conta que Discépolo já experimentara o enfoque crítico em seus primeiros tangos compostos na década de 1920, proponho considerar uma rede de filiações intertextuais, que permitem ampliar o enfoque sobre os tangos, descolando-os do imediato político, para abordá-los a partir da experiência traumática e mais generalizada da modernidade, vivida tanto no contexto argentino quanto europeu.

\section{De El hombre a la defensiva a El hombre que está solo y espera}

11 Ao estudar o campo literário argentino entre 1930 e 1943, María Teresa Gramuglio (2001) adota uma perspectiva crítica em relação às representações da crise dos anos 1930. Observa que o "sentimiento generalizado de catástrofe" entre a intelectualidade da década de 1930 não é uma especificidade argentina, e que "tener en cuenta este panorama ayudaría a destrabar una visión excesivamente ensimismada en las desventuras locales" 
(GRAMUGLIO, 2001: 336). A intenção da autora é "cuestionar ese mecanismo que traslada rectamente las evaluaciones de la esfera política a la literaria", o que "implica además admitir que no existe una sincronía absoluta entre los fenómenos político-sociales y la evolución de los procesos culturales y literarios" (Idem: 337). Gramuglio critica ainda a tendência a invocar palavras recorrentes nos títulos de obras do período, como "soledad", "silencio", "infamia", sem a análise dos textos. ${ }^{5}$

É o caso do famoso ensaio de Raúl Scalabrini Ortiz, El hombre que está solo y espera, que, uma vez associado à "década infame", será sempre lembrado como o retrato daquela experiência social. Lançado em 1931, esgotaram-se quatro edições em apenas quatro meses. Segundo Gramuglio, porém, a sensibilidade que o livro expressa, ligada ao otimismo das vanguardas literárias dos anos 1920, seria "bastante menos lúgubre de lo que su título parece sugerir" (Idem: 337). Para Gramuglio, "más que un resultado de la desazón provocada por la crisis económica", o ensaio "es una respuesta amable a ciertas imágenes críticas de la Argentina y de los argentinos elaboradas por algunos viajeros europeos", nomeando em particular a El hombre a la defensiva, ensaio publicado por Ortega y Gasset em 1929 (Idem: 337). ${ }^{6}$

13 Seguindo a sugestão da autora, se analisamos o texto do filósofo espanhol, algumas aproximações são bem perceptíveis: Ortega y Gasset pretende "penetrar en el alma individual del hombre argentino", e reforça: "conste - del hombre", excluindo a mulher (ORTEGA Y GASSET, 1929: 222). O título, El hombre a la defensiva, explica-se pela forma negativa com que seu autor avalia o meio intelectual argentino, no qual, segundo ele, predomina a incompetência, disfarçada na firmeza com que se defende a posição social ou a função pública desempenhada. Criticando uma suposta vaidade e retraimento do argentino, diz: "siento no conocer bien la zona secreta de las relaciones eróticas en la Argentina, porque fuera ese territorio delicadísimo el lugar más a propósito para confirmar o desechar mi diagnóstico" (Idem: 247). E indaga, dando o mote que seria seguido por Scalabrini Ortiz:

¿Es el argentino un buen amador? ¿Tiene vocación de amar? ¿Sabe enajenarse? ¿O, por el contrario, más que amar él se complace en verse amado, buscando así en el suceso erótico una ocasión más para entusiasmarse consigo mismo? (Idem: 247)

Entendo portanto que a menção a "el hombre" no título do ensaio de Scalabrini Ortiz, e também no arquétipo que ele nomeia no livro - "El Hombre de Corrientes y Esmeralda" -, somado à ênfase que dá ao comportamento sexual do porteño, confirmam a intenção de responder ou de se desviar de algumas indagações e conclusões de Ortega y Gasset. E entendo ainda que tudo isso é mais claro ainda pelo fato de o autor eleger o comportamento do porteño frente ao tango como parâmetro descritivo. Naquele que é talvez o capítulo mais importante do livro, intitulado "El Hombre de Corrientes y Esmeralda", Scalabrini diz: "me dilaté en la nada fatua sino imprescindible creación de un hombre arquetipo de Buenos Aires: el Hombre de Corrientes y Esmeralda", descrito como "polo magnético de la sexualidad porteña", que "es, además, el protagonista de una novela planeada por mí, que ojalá alguna vez alcance el mérito de no haber sido publicada", mas que servirá de "instrumento que permitirá hincar la viva carne de los hechos actuales, y en la vivisección descubrir ese espíritu de la tierra que anhelosamente busco" (SCALABRINI ORTIZ, 2007: 50). Essa oscilação entre um ensaio e uma novela e ao fim o caráter algo mitológico com que elabora seu texto dão conta de um irracionalismo que será objeto da mencionada análise de Gramuglio, e também das considerações de Sarlo, Cattaruzza e Rodríguez, e Naomi Lindstrom, que associa o texto ao "postulado 
vanguardista que define la vida misma como un fenómeno desordenado incompatible con el análisis riguroso" (LINDSTROM, 1985: 196). Scalabrini dirá ainda:

El Hombre de Corrientes y Esmeralda es hombre de improvisaciones y no de planes, es un hombre fiado en la certeza del instinto, en sus intuiciones, sus presentimientos. En una palabra: es el hombre del 'pálpito'. El Hombre de Corrientes y Esmeralda no reflexiona. Ignora ese escalonamiento de la cordura que es la deliberación. [...] El porteño no piensa, siente. Siento, luego existo, es un aforismo más apropiado que el cartesiano. (SCALABRINI ORTIZ, 2007: 82) ${ }^{7}$

Para Gramuglio, "Scalabrini introdujo en su ensayo un tópico que iba a ser clásico del nacionalismo populista: el antiintelectualismo" (GRAMUGLIO, 2001: 349). A crítica de Scalabrini aos intelectuais é, no meu entender, mais um ponto de articulação entre seu texto e o de Ortega y Gasset. Em 1929, o filósofo espanhol lamentava que no país "haya faltado una minoría enérgica que suscite una nueva moral en la sociedad, llame al argentino a si mismo, a su efectiva intimidad y sinceridad [...], le fuerce a vivir verdaderamente" (ORTEGA y GASSET, 1929: 257). ${ }^{8}$ Aliando irracionalismo e antiintelectualismo, o próprio Scalabrini responderá à crítica, censurando a "inteligencia conceptual, que se nutre de libros, de teorías y no de sensaciones", que "no escolta el espíritu de la tierra" (SCALABRINI ORTIZ, 2007: 83), e que "por eso el Hombre de Corrientes y Esmeralda se reconoce más en las letras de tango, en sus jirones de pensamiento, en su hurañía, en la poquedad de su empirismo", que o autor contrapõe aos "fatuos ensayos o novelas o poemas que interfolian la antepenúltima novedad francesa, inglesa o rusa" (Idem: 87$){ }^{9}$

O próprio Scalabrini Ortiz acabará desempenhando simbolicamente o papel daquela minoria enérgica a que se referia Ortega y Gasset, capaz de chamar o argentino a si mesmo. Rapidamente, ele será convertido em um "intérprete da alma nacional". ${ }^{10} \mathrm{E}$ não só ele, também Enrique Santos Discépolo, sobretudo à força dos embates políticos da década de 1960, será associado ao ensaísta e ainda receberá o epíteto de "filósofo callejero", por contraposição ao intelectualismo atribuído a Jorge Luis Borges. A oposição entre o escritor e o tanguero será reiteradamente apontada na biografia de Discépolo publicada por Norberto Galasso em 1967 (GALASSO, 2004). Por sua vez, Horacio Ferrer e Luis Sierra, em outra biografia do poeta, de 1965, levarão ao título de seu livro o próprio arquétipo criado por Scalabrini Ortiz: Discepolín: poeta del hombre que está solo y espera (2004). Além disso, em seu livro de estreia, publicado em 1967, Ferrer, ele próprio poeta além de estudioso do tango e que seria depois autor de diversos tangos compostos em parceria com Piazzolla, retomaria outra vez o diálogo com o ensaio de Scalabrini, num poema intitulado "Solo y espera", que conclui entre o melancólico e o grotesco:

$\mathrm{Y}$, al fondo a la derecha de la gente,

mi taza de café era una letrina

donde flotaba yo, grotescamente. (FERRER, 1999: 63)

Seguramente, essas associações não têm nenhuma gratuidade. Assim como o poema de Ferrer, os versos de Cafetín de Buenos Aires de Discépolo podem ser interpretados numa relação intertextual com o ensaio de Scalabrini Ortiz. A releitura de Discépolo é provavelmente uma interpretação bastante fiel do mito criado em torno daquele "Hombre de Corrientes y Esmeralda", "que está solo y espera". O ensaísta situara seu personagem igualmente arquetípico para a identidade porteña num café de Buenos Aires, onde a amizade é exaltada como um valor oposto aos contravalores da modernidade: "allí está con un camarada en el fortín de la amistad" (SCALABRINI ORTIZ, 2007: 115). E 
Discépolo replica: "me diste en oro un puñado de amigos / que son los mismos que alientan mis horas" (ROMANO, 2007: 376).

Scalabrini ressalta ainda o caráter acolhedor do café como uma proteção ante as vicissitudes e ameaças da vida na grande cidade: "allí está seguro [...]. Fuera del reducto amistoso, la vida dañina ralea la dignidad y el número de los hombres, pero allí dentro es inofensiva" (SCALABRINI ORTIZ, 2007: 116). De forma análoga, como vimos, Discépolo associa o acolhimento desse "reducto amistoso" ao aconchego materno: "sos lo único en la vida / que se pareció a mi vieja" (ROMANO, 2007: 376). Com a prolixidade da prosa literária e mitogenética, Scalabrini pinta a cena:

El café rebosa... las mujeres están excluidas de esa grey. Son hombres que hablan poco y en voz baja, como si bisbisearan un rezongo. Suena un tango, la densidade del silencio se intensifica. Cesan los rumores y los ruidos. Todos callan. El café es un templo de atrición. Los hombres encorvan ligeramente sus testas y distraen sus ojos en el borde de la taza en que desprenden la ceniza de los cigarrillos. Meditan. Están ensimismados. Hurgan sus días irreconciliablemente distanciados de la realidade. Divagan. En su fantasía moldean sus vidas como una miga de pan. La desunen, la reconstruyen, la llenan de perspectivas. Son artistas sin otras materias plásticas que sus propias existencias. Sueñan. Es una decepción más que se infiltra en suas ánimos cuando el tango termina, los ojos cansados tienen rastros de un desgano que conoció la aventura. (SCALABRINI ORTIZ, 2007: 73)

E Discépolo ecoa, com a concisão poética dos versos:

Sobre tus mesas que nunca preguntan

lloré una tarde el primer desengaño,

nací a las penas,

bebí a mis años

y me entregué sin luchar. (ROMANO, 2007: 376)

Longe de serem apenas coincidências, essas retomadas sucessivas dos temas e situações revelam um jogo de apropriações e reiterações, que contribuem para moldar ou reforçar uma sensibilidade haurida na experiência histórica, mas construída sobre um aparato discursivo que implica escolhas com um certo grau de invenção e intenção, e que terminam por confirmar uma representação identitária que atribui ao argentino ou ao menos ao porteño traços de um caráter definido pela melancolia e pelo pessimismo ante a realidade social. Obviamente que a sociabilidade construída em torno dos cafés poderia indicar outro modo de estar no mundo e o descrever, menos afeito ao negativismo e conforme a uma possível alegria de compartilhar o tempo livre. Mas trata-se mesmo de uma eleição e de uma obsessão, em que os sujeitos reforçam os traços mais lúgubres da experiência, resultando nessa ficcionalização quase caricatural do real. Mas observo que essas escolhas cumprem uma espécie de programa ou função política, ao dotar as identidades aí construídas de um tom de protesto, reivindicatório, que encontrará canalização em diferentes culturas políticas, como a radical em um primeiro momento e a peronista em seguida.

\section{A cidade, a multidão e o choque}

21 Como um tango nunca vem sozinho, a mesma estética do desencanto válida para a análise dos tangos de Discépolo pode ser lida nos versos de outro poeta tanguero, Homero Manzi, que em Discepolín, escrito em 1951, em homenagem ao autor do Cafetín de Buenos Aires, soube captar a essência do que o poeta exterioriza em seus versos, e propor um diálogo 
com seus temas: "conozco de tu largo aburrimento / y comprendo lo que cuesta ser feliz" (ROMANO, 2007: 400). Por trás da aparência de um drama excessivamente personalista, Manzi sublinha o encontro do poeta com o meio social: "te duele como propia la cicatriz ajena; / aquél no tuvo suerte, y ésta no tuvo amor". Não falta a esses versos a referência ao onipresente café, em cujas mesas com tampo de mármore, o poeta, boêmio, contempla, tresnoitado, a passagem do tempo, como a marcar o ritmo frenético de um mundo que segue seu curso, sem se importar com a dor alheia:

Sobre el mármol helado, migas de medialuna

y una mujer absurda que come en un rincón;

tu musa está sangrando y ella se desayuna:

el alba no perdona, no tiene corazón. (ROMANO, 2007: 400)

Em 1943, antes da composição de Cafetín de Buenos Aires, Manzi já tocara o tema do café como locus de onde o poeta contempla simultaneamente o tempo presente da cidade modernizada e o tempo passado de suas lembranças particulares. Em Mi taza de café, com música de Alfredo Malerba, o autor chega a questionar seu "inútil pesimismo, deseo de estar triste" e o próprio sentimento melancólico, que insiste em revolver o passado, com sua "manía de andar siempre pensando en el ayer". Assim como em Cafetín de Buenos Aires e em Discepolín, é o café a grande janela aberta sobre a cidade e a existência:

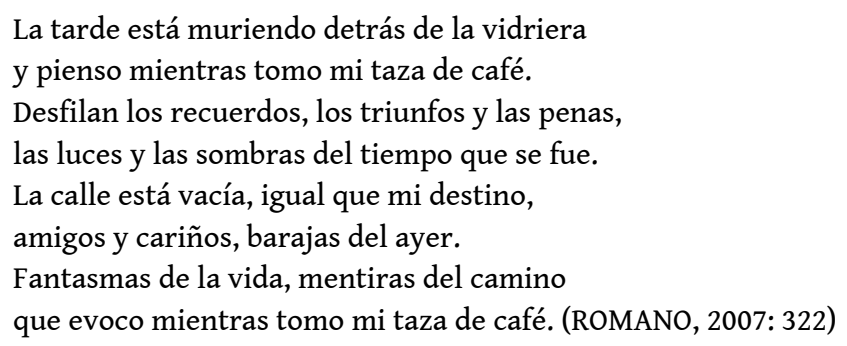

23 A experiência urbana, da solidão em meio à grande cidade, que muitos tangos traduzem, pode ser aproximada de outras considerações também de Ortega y Gasset. Em sua visita de 1928 ao país, o filósofo abordou o tema que conduziria a seu conhecido ensaio A rebelião das massas. Embora só publicado na forma de livro posteriormente, muitas das ideias ali expressas deixariam uma forte marca sobre a intelectualidade argentina. Ortega y Gasset parte da mesma constatação que muitos intelectuais argentinos já haviam feito no final do século anterior: a emergência das massas, das multidões, que, "agora, de repente, aparecem sob a forma de aglomeração", e que levam o filósofo a abordar o fenômeno como uma experiência antes de tudo visual: "nossos olhos vêem multidões por toda parte" (ORTEGA Y GASSET, 2007: 43). Assustado por essas massas urbanas que "se tornaram indóceis diante das minorias" (Idem: 52), o filósofo enuncia uma crise que propõe mais interrogações do que certezas:

Rechaço pois, igualmente, qualquer interpretação de nosso tempo que não considere a significação positiva oculta sob o atual império das massas, bem como as que o aceitam pacificamente, sem estremecer de espanto. Todo destino é, no fundo, dramático e trágico. Quem não sentiu o perigo do tempo palpitar em suas mãos não chegou às entranhas do destino, não fez mais que tocar sua mórbida face. No nosso, o ingrediente terrível é colocado pela avassaladora e violenta sublevação moral das massas, imponente, indomável e equívoca como todo destino. Aonde nos leva? É um mal absoluto, ou um bem possível? Aí está, colossal, instalada em nosso tempo como um gigante, signo cósmico de interrogação, que tem sempre uma forma equívoca que lembra, de fato, uma guilhotina ou uma forca, mas também um possível arco triunfal. (Idem: 51-52) 
perder de vista a experiência argentina, é possível religar todas essas percepções a outras, mais amplas. O mote é dado pela metáfora que empreguei, ao comentar o tango de Manzi, Mi taza de café: o café como janela aberta sobre a cidade e através da qual o poeta a contempla, e comenta as experiências pessoais e coletivas. Essa percepção remete diretamente a um diálogo com alguns temas da lírica de Charles Baudelaire já explorados por Walter Benjamin e por Marshall Berman: a cidade, a multidão, a boêmia, a flânerie, o choque, a melancolia, a própria modernidade. Analisando a inserção de Baudelaire na modernidade, Benjamin elabora seu estudo sobre o poeta a partir da investigação quanto ao modo pelo qual "a poesia lírica poderia estar fundamentada em uma experiência, para a qual o choque se tornou norma" (BENJAMIN, 1994: 110). O crítico alemão concluirá vendo As Flores do Mal como "a última obra lírica a exercer influência no âmbito europeu", reconhecendo que ao mesmo tempo seus temas "colocam em questão a possibilidade mesma de uma poesia lírica" (Idem: 143). o choque a que se refere Benjamin é a própria experiência, vivida de forma traumática, de abrir seu caminho na multidão. O poeta entretanto parecia oscilar entre uma avaliação positiva e outra pessimista diante das transformações.

Em seu ensaio sobre o desenhista, aquarelista e gravador Constantin Guys, escrito em 1859-60 e intitulado 0 pintor da vida moderna, Baudelaire remete ao "quadro" escrito por Edgar Allan Poe, 0 homem da multidão, extraindo daí algumas valiosas sugestões para o entendimento da vida moderna e do olhar que se dedica a expressá-la:

Atrás das vidraças de um café, um convalescente, contemplando com prazer a multidão, mistura-se mentalmente a todos os pensamentos que se agitam à sua volta. Resgatado há pouco das sombras da morte, ele aspira com deleite todos os indícios e eflúvios da vida; como estava prestes a tudo esquecer, lembra-se e quer ardentemente lembrar-se de tudo. Finalmente, precipita-se no meio da multidão à procura de um desconhecido cuja fisionomia, apenas vislumbrada, fascinou-o num relance. A curiosidade transformou-se numa paixão fatal, irresistível! (BAUDELAIRE, 2004: 18)

Como retratará Manzi em seu tango, o café é a janela que se abre sobre a cidade moderna e sua multidão de seres em movimento. Porém, ao contrário de Poe, Baudelaire e Ortega y Gasset, Manzi esvaziará as ruas, substituindo o desfile de todas as coisas dadas à contemplação pelo desfile das recordações mais íntimas, e a fantasmagoria dos passantes urbanos pelos "fantasmas de la vida". Ensimesmado e cego ao que se dá à sua volta, Manzi parece tocado pelo spleen, pela melancolia, pelo tédio, que alimentam a introspecção, mais do que pela contemplação do palpitar da vida lá fora. "Multidão, solidão: termos iguais e conversíveis pelo poeta ativo e fecundo", dirá Baudelaire em um de seus poemas em prosa, intitulado justamente As multidões (BAUDELAIRE, 2006: 67).

Mas para o poeta, o que marca o pintor da vida moderna, como um modelo valorizado, e de fato assumido em sua própria obra poética, é a capacidade de se entregar a esse estado de convalescença, que funcionaria como uma volta à infância, na qual tudo é visto como novidade, numa embriaguez dos sentidos, para a qual nenhum aspecto da vida é indiferente. Baudelaire chega a caracterizá-lo como um filósofo, mas descarta essa imagem, preferindo a de "puro moralista pitoresco". Na sequência de personagens que evoca para tentar qualificá-lo, contrasta à insensibilidade do dandy, entediado e desinteressado em meio às multidões, a entrega do flâneur, cuja paixão e profissão é “épouser la foule”, isto é, desposar a multidão:

"Para o perfeito flâneur, para o observador apaixonado, é um imenso júbilo fixar residência no numeroso, no ondulante, no movimento, no fugidio e no infinito. 
Estar fora de casa, e contudo sentir-se em casa onde quer que se encontre; ver o mundo, estar no centro do mundo e permanecer oculto no mundo, eis alguns dos pequenos prazeres desses espíritos independentes, apaixonados, imparciais, que a linguagem não pode definir senão toscamente. 0 observador é um príncipe que frui por toda parte do fato de estar incógnito. [...] Pode-se igualmente compará-lo a um espelho tão imenso quanto essa multidão; a um caleidoscópio dotado de consciência, que, a cada um de seus movimentos, representa a vida múltipla e o encanto cambiante de todos os elementos da vida." (BAUDELAIRE, 2004: 21) as vidas de homens e mulheres na multidão não merecerá ser chamada propriamente de arte moderna" (BERMAN, 1987: 142). Por isso, entregue à contemplação das tardes ensolaradas e da iluminação artificial das noites, o pintor "será o último a partir de qualquer lugar onde possa resplandecer a luz, ressoar a poesia, fervilhar a vida, vibrar a música", para enfim recolher-se, "à hora em que os outros estão dormindo", e curvar-se sobre sua mesa, "lançando sobre uma folha de papel o mesmo olhar que há pouco dirigia às coisas" (BAUDELAIRE, 2004: 23). Assim é que a percepção infantil, ingênua, retemperada pelo espírito analítico da genialidade, dará origem então à obra de arte moderna. Por sua vez, as referências à luz, à poesia, à música, justapostas por Baudelaire sinestesicamente à vida, indicam de que matéria será feita sua própria poesia.

A necessidade dessa entrega do artista ao mundo das coisas exteriores será o que marcará os poemas em prosa, escritos na década de 1860, e que Baudelaire pretendia publicar sob o título Spleen de Paris, e efetivamente publicados em 1868, um ano após sua morte. Nestes, o poeta propõe "uma prosa poética, musical, sem ritmo e sem rimas", maleável e adaptável aos movimentos líricos da alma, um ideal, segundo ele, nascido da "frequentação das enormes cidades e do crescimento de suas inumeráveis relações" (BAUDELAIRE, 2006: 17). Berman salienta a peculiaridade de esses poemas não se apresentarem na forma estabelecida de versos, mas como prosa, "no formato das notícias" (BERMAN, 1987: 144), numa aproximação já sinalizada por Benjamin a esses importantes fatores de transformação da narrativa e da percepção do mundo moderno, que são a imprensa e o folhetim. Uma chave de leitura para a produção de Baudelaire estaria, segundo Berman, no processo de modernização por que passa Paris no II Império:

Enquanto trabalhava em Paris, a tarefa de modernização da cidade seguia seu curso, lado a lado com ele, sobre sua cabeça e sob seus pés. Ele pôde ver-se não só como um espectador, mas como participante e protagonista dessa tarefa em curso; seus escritos parisienses expressam o drama e o trauma aí implicados. Baudelaire nos mostra algo que nenhum escritor pôde ver com tanta clareza: como a modernização da cidade simultaneamente inspira e força a modernização da alma dos seus cidadãos. (BERMAN, 1987: 143)

31 Num dos poemas destacados por Berman, Os olhos dos pobres, um idílio amoroso é atravessado pela questão social. Um casal enamorado anseia pela comunhão de sentimentos na troca muda dos olhares. $\mathrm{O}$ ambiente escolhido por Baudelaire para situar esse idílio na atmosfera moderna da cidade em transformação é precisamente "um café novo, na esquina de um boulevard também novo, ainda cheio de cascalhos, mas já mostrando gloriosamente seus esplendores inacabados" (BAUDELAIRE, 2006: 147). Desde já o café e o boulevard serão os ícones dessa modernidade parisiense, emulada por tantas cidades pelo mundo afora. Mas a cidade moderna não será apenas beleza e êxtase contemplativo. Diante do olhar admirado de um pai acompanhado dos dois filhos, todos vestidos em farrapos, o narrador se revela compadecido pela visão da pobreza em 
contraste com o luxo desses novos equipamentos com que se ia revestindo a cidade moderna: "não somente eu estava enternecido por esta família de olhos, como me sentia envergonhado por nossos copos e nossas garrafas, maiores que nossa sede" (BAUDELAIRE, 2006: 149). O espetáculo da pobreza termina interrompendo o idílio do casal, quando o narrador constata que a seu enternecimento se contrapõe a repulsa da companheira.

Mesmo antes dessas transformações urbanas, que expõem à vista tanto a beleza quanto as contradições da modernidade, a lírica de Baudelaire, embora conservasse a forma clássica de metro e rima, recorrendo constantemente ao soneto, já era portadora de signos novos, perceptíveis no vocabulário, nos temas e nos personagens. No conteúdo de sua poesia, poderíamos dizer. Observando que o poeta não descreve nem a população, nem a cidade, optando antes por "evocar uma na imagem da outra", Benjamin é levado a afirmar que "sua multidão é sempre a da cidade grande; a sua Paris é invariavelmente superpovoada" (BENJAMIN, 1994: 116). Partindo de Benjamin e em complemento a suas análises, Berman sublinha em Spleen de Paris o que chama de "cenas modernas primordiais", isto é, experiências que brotam da vida cotidiana da Paris de Bonaparte e Haussmann, porém "impregnadas de uma ressonância e uma profundidade míticas que as impelem para além de seu tempo e lugar, transformando-as em arquétipos da vida moderna" (BERMAN, 1987: 144).

Perda da auréola é um dos poemas em prosa de Baudelaire (2006: 252-255), em que Berman (1987: 150-159) vê uma situação arquetípica para a modernidade. Um poeta, lançando-se à aventura de atravessar o boulevard em meio à profusão de carros e cavalos que o cortam em disparada, deixa cair sua auréola sobre a lama do macadame. Em vez de se abaixar para apanhá-la, deixa-a ficar e aproveita que agora é um poeta incógnito na multidão dos homens comuns, para meter-se em algum lugar sórdido, possivelmente um bordel, que a recatada poesia não costumava acessar. (A prostituição aliás é um tema caro à poesia de Baudelaire, como será para os tangueros argentinos.) Remeto a Benjamin e a Berman para as interpretações que vêem aí aproximações entre Baudelaire e Marx, quanto à dessacralização do mundo promovida pela burguesia, sob o império da qual, tudo é transformado em mercadoria.

Mas o que também me chama a atenção no poema, para os fins aqui propostos, é essa aproximação que Baudelaire propõe entre a poesia e a lama, "la fange du macadam". o termo francês, como demonstra Berman (1987: 155), associado à ideia de lama, lodo, mas também de baixeza, corrupção, degradação, cairá como uma luva na poética tanguera. Importado do italiano e incorporado ao vocabulário lunfardo, acusado este pelos puristas de ser a degradação da língua espanhola culta, tomará a forma fango, tão apropriadamente apto a rimar com tango, como nos precursores versos que Pascual Contursi escreveu em 1917 em Flor de fango:

Fuiste papusa del fango

$\mathrm{y}$ las delicias de un tango

te espiantaron del bulín;

los amigos te engrupieron

y ellos mismos te perdieron

noche a noche en el festín. (ROMANO, 2007: 32)

A descrição da trajetória decadente da jovem suburbana entregue aos luxos e prazeres, que a levam à prostituição e ao abandono final, marca o tema clássico desenhado entre a denúncia moral e o protesto social pela situação de vulnerabilidade em que se encontravam tantas jovens pobres, filhas de trabalhadores, sobretudo imigrantes. ${ }^{11}$ Esta é 
mais uma das facetas com que os autores de tango-canción expressam o descontentamento com as contradições inerentes ao processo modernizador. Outra é a alteração da própria paisagem, que aos poucos incorpora ao território urbano em expansão bairros fronteiriços entre a cidade e o campo. Homero Manzi será o grande cantor dessa nostalgia pelos antigos bairros, como em Barrio de Tango, de 1942:

Barrio de tango, luna y misterio,

calles lejanas, ¡cómo estarán!

[...]

Así evoco tus noches, barrio de tango,

con las chatas entrando al corralón

y la luna chapaleando sobre el fango

y a lo lejos la voz del bandoneón. (ROMANO, 2007: 318)

Porém, na transposição operada pelos poetas tangueros, o fango não será o do moderno macadame de que fala Baudelaire, mas a lama dos bairros pobres e operários, mais distantes do centro, inundáveis pela cercania das águas do Riachuelo. A rima, no caso, presta-se a lembrar ao ouvinte uma origem popular do tango, refratária ao aristocratismo das oligarquias, cuja intervenção no espaço urbano propicia alguma mobilidade ascendente, mas não elimina as contradições, que, evidentemente se acirrarão com a crise de 1929-30.

São algumas das formas arquetípicas da poesia lírica de Baudelaire que me parecem penetrar o mundo do tango-canción, desenvolvido a partir da década de 1920, e que terá em Discépolo e Manzi dois de seus mais significativos autores. 0 impacto da experiência modernizadora vivida por Baudelaire na Paris do século XIX pode ser visto transposto à Buenos Aires das primeiras décadas do século seguinte. Nos tangos, os narradores mostram-se também observadores dos efeitos da modernização, mas o estímulo que esta propicia leva-os a lamentar uma espécie de paraíso perdido, arrancado ao seio à força da remodelação da paisagem. Nos tangos, o desamparo, a denúncia, a queixa, disfarçados sob a capa do desencontro amoroso, estarão contidos numa reflexão metafísica sobre o tempo que passa inexorável ou numa carga moralizante com que é condenada a modernização. Como um flâneur bonaerense, o autor de tangos percorre as ruas de sua cidade, registrando as impressões que logo serão transpostas aos versos da nova canção de sucesso, descrevendo tipos, ambientes e situações. Como um dandy, entediado, pode também alienar-se de tudo à sua volta e fechar-se em ruminações íntimas sobre seu desconforto pessoal.

$\mathrm{Na}$ aceleração da vertigem modernizadora trazida pelo século $\mathrm{XX}$, o disco e o rádio cumprirão a tarefa de amplificar as vozes desses poetas, ao encontro de um público que, a partir delas, parece construir uma nova identidade em conjunção com a cidade moderna. Estamos agora diante de um tema não só baudelairiano, mas também benjaminiano, o da perda da auréola em Baudelaire, perda da aura em Benjamin. Produzido em escala mercantil e viabilizado pelas modernas técnicas industriais de reprodução e difusão, o tango-canción é mercadoria, música de consumo, de entretenimento e de fruição, mas também veículo para o protesto e para a construção de identidades sociais. Além disso, é também uma forma de poesia "popular", formada na confluência entre a tradição lírica e a dramática, em diálogo com várias referências e poéticas que foram apropriadas por seus autores, reconhecíveis ou não por seu público consumidor e fruidor. Vale lembrar que Discépolo chegou ao tango pelo teatro, e pelo grotesco como gênero, e o citado Homero Manzi atuou nos anos 1920 como professor de Língua e Literatura. 
Sem dúvida, muitos dos temas baudelairianos, entendidos como os arquétipos a que se refere Berman, reaparecem no desenvolvimento do tango-canción, que procuro entender aqui como outra tentativa de perpetuação da lírica em meio à modernidade. À diferença do poeta francês, que oscila entre um negativismo crítico e um otimismo, seus autores assumiram preferencialmente em seus versos um enfoque pessimista, testemunhando as fortes tensões sociais vivenciadas como a contraface da modernidade. Muitos, como Discépolo e Manzi, eram filhos de imigrantes que tinham vivido as vicissitudes da modernização acelerada por que passara Buenos Aires desde o fim do século, e trouxeram a dureza dessas experiências sociais para a poética tanguera. Reforçada pela crise dos anos 30 , essa percepção terminaria assumindo um viés fortemente identitário e reivindicativo de uma condição social subalterna ante uma conformação social que lhes parecia sempre injusta. Assim, se por um lado podiam ressoar modelos poéticos e as formulações dos ensaios explicativos, também reelaboravam seus temas, dotando-os de um viés fortemente político que lhes convinha como ferramenta de ação.

\section{BIBLIOGRAFIA}

BAUDELAIRE Charles, As flores do mal. Tradução de Ivan Junqueira, Rio de Janeiro, Nova Fronteira, 2012. (Edição Bilíngue.)

BAUDELAIRE Charles, Oeuvres complètes, Paris, Seuil, 1968.

BAUDELAIRE Charles, Pequenos poemas em prosa. Tradução de Gilson Maurity, Rio de Janeiro, São Paulo, Record, 2006. (Edição Bilíngue)

BAUDELAIRE Charles, Sobre a modernidade. 4. ed., Rio de Janeiro, Paz e Terra, 2004.

BENJAMIN Walter, Charles Baudelaire: um lírico no auge do capitalismo. 3. ed. Obras escolhidas. Volume III. Tradução de José Carlos Martins Barbosa e Hemerson Alves Baptista, São Paulo, Brasiliense, 1994.

BENJAMIN Walter, A obra de arte na época de suas técnicas de reprodução. dans Textos escolhidos. Tradução de José Lino Grünewald, São Paulo, Abril Cultural, 1975, p. 9-34. (Os Pensadores)

BERMAN Marshall, Baudelaire: o modernismo nas ruas, dans Tudo que é sólido desmancha no ar: a aventura da modernidade. Tradução de Carlos Felipe Moisés e Ana Maria L. Ioriatti, São Paulo, Companhia das Letras, 1987, p. 127-165.

CAMPRA Rosalba, Como con bronca y junando... la retórica del tango, Buenos Aires, Edicial, 1996.

CATTARUZZA Alejandro, RODRÍGUEZ Fernando, Prefacio: una vez más, El hombre que está solo y espera, dans Raúl SCALABRINI ORTIZ, El hombre que está solo y espera, Buenos Aires, Biblos, 2007, p. 9-32.

CIBOTTI Ema, Del habitante al ciudadano: la condición del inmigrante, dans El progreso, la modernización y sus límites: 1880-1916, sous la direction de Mirta Zaida LOBATO, Buenos Aires, Sudamericana, 2000, p. 365-408. (Nueva historia argentina, t. V.) 
CONDE Oscar, Enrique Santos Discépolo: la rebelión contra el mundo, dans Poéticas del tango, sous la direction de Oscar CONDE, Buenos Aires, Marcelo Héctor Oliveri, 2003, p. 57-96.

FERRER Horacio, Romancero canyengue: versos lunfas y grotescos. 2. ed., Buenos Aires, Peña Lillo, Continente, 1999. (A $1^{\mathrm{a}}$ edição é de 1967.)

FERRER Horacio, SIERRA Luis, Discepolín: poeta del hombre que está solo y espera. $2^{\mathrm{a}}$ ed, Buenos Aires, Sudamericana, 2004. (A 1ª edição é de 1965.)

FRAGA Enrique, La prohibición del lunfardo en la radiodifusión argentina: 1933-1953, Buenos Aires, Lajouane, 2006.

FREUD Sigmund, Luto e melancolia, dans Introdução ao narcisismo: ensaios de metapsicologia e outros textos: 1914-1916. Tradução de Paulo César de Souza, São Paulo, Companhia das Letras, 2010, p. 170-194. (Obras completas, vol. 12.)

GALASSO Norberto, Discépolo y su época, Buenos Aires, Corregidor, 2004. (A 1ª edição é de 1967.)

GAYOL Sandra, Ambitos de sociabilidad en Buenos Aires: despachos de bebidas y cafés, 1860-1900, Anuario IEHS, Tandil, n. 8, 1993, p. 257-273.

GRAMUGLIO María Teresa, Posiciones, transformaciones y debates en la literatura. dans Crisis económica, avance del Estado y incertidumbre política: 1930-1943, sous la direction de Alejandro CATTARUZZA, Buenos Aires, Sudamericana, 2001, p. 331-381. (Nueva historia argentina, t. VII.)

GUTMAN Margarita, REESE Thomas, Buenos Aires 1910: el imaginario para una gran capital, Buenos Aires, Eudeba, 1999.

JARAMILLO Ana, Fueye y melancolía: los intelectuales y el suicidio, Buenos Aires, LC, 1995.

LINDSTROM Naomi, Scalabrini Ortiz: el lenguaje del irracionalismo, Revista Iberoamericana, Madri, vol. LI, n. 130-131, , jan.-jun. 1985, p. 185-196.

LOBATO Mirta Zaida (dir.), El progreso, la modernización y sus límites: 1880-1916, Buenos Aires, Sudamericana, 2000. (Nueva historia argentina, t. V.)

MARTÍNEZ MOIRÓN Jesús, El mundo de los autores: incluye la historia de SADAIC, Buenos Aires, Sampedro, 1971.

ORTEGA Y GASSET José, El hombre a la defensiva, El espectador, Tomo VII, Madrid, Revista de Occidente, 1929.

ORTEGA Y GASSET José, A rebelião das massas. Tradução de Marylene Pinto Michael, São Paulo, Martins Fontes, 2007.

PELLETTIERI Osvaldo, Enrique Santos Discépolo: obra poética, Buenos Aires, Todo es Historia, SRL, 1976.

PEREIRA Avelino Romero, Buenos Aires, história e tango: crise, identidade e intertexto nas narrativas tangueras, Tese (Doutorado em História) - Universidade Federal Fluminense, Niterói, 2012a.

PEREIRA Avelino Romero, "La vida es una herida absurda": representações da melancolia no tango, Anamorfose, Revista de Estudos Modernos, Rio de Janeiro, vol. 2, n. 2, 2014a, p. 31-54.

PEREIRA Avelino Romero, Luto e melancolia, memória e identidade: do tango ao nuevo tango de Astor Piazzolla, Escritos, Revista da Fundação Casa de Rui Barbosa, Rio de Janeiro, ano 6, n. 6, p. 159-183, 2012b.

PEREIRA Avelino Romero, "Malena canta el tango como ninguna": o tango em feminino. ArtCultura, Uberlândia, v. 16, n. 28, p. 7-21, jan.-jun. 2014b. 
PUJOL Sergio, Discépolo: una biografía argentina, Buenos Aires, Booket, 2006.

RIVERA Jorge B., 10 perfiles de Discépolo en 4x4, Crisis, Buenos Aires, ano 1, n. 7, p. 10-13, nov. 1973.

ROMANO Eduardo (org.), Las letras del tango: antología cronológica: 1900-1980. 5. ed., Rosario, Fundación Ross, 2007.

ROMERO José Luis, La Ciudad Burguesa, dans Buenos Aires: historia de cuatro siglos, sous la direction de José Luis ROMERO, Luis Alberto ROMERO, 2. ed. ampliada y actualizada, Buenos Aires, Altamira, 2000a, p. 9-17.

ROMERO José Luis, La Ciudad de Masas, dans Buenos Aires: historia de cuatro siglos, sous la direction de José Luis ROMERO, Luis Alberto ROMERO, 2. ed. ampliada y actualizada, Buenos Aires, Altamira, 2000b, p. 201-208.

SAÍTTA Sylvia, Posfacio: una biblia porteña: El hombre que está solo y espera de Raúl Scalabrini Ortiz, dans Raúl SCALABRINI ORTIZ, El hombre que está solo y espera, Buenos Aires, Biblos, 2007, p. 143-158.

SARLO Beatriz, Una modernidad periférica: Buenos Aires, 1920 y 1930. 1. ed., 4. reimpr., Buenos Aires, Nueva Visión, 2007.

SCALABRINI ORTIZ Raúl, El hombre que está solo y espera, Buenos Aires, Biblos, 2007. (A $1^{\text {a }}$ edição é de 1931.)

TERÁN Oscar, Historia de las ideas en la Argentina: diez lecciones iniciales: 1810-1980, Buenos Aires, Siglo XXI, 2008.

TRONCOSO Oscar A., Las nuevas formas del ocio, dans Buenos Aires: historia de cuatro siglos, sous la direction de José Luis ROMERO, Luis Alberto ROMERO, 2. ed. ampliada y actualizada, Buenos Aires, Altamira, 2000, p. 285-294.

VARDARO Arcángel Pascual, La censura radial del lunfardo: 1943-1949: con especial aplicación al tango, Buenos Aires, Dunken, 2007.

WARLEY Jorge A., Vida cultural e intelectuales en la década de 1930, Buenos Aires, CEAL, 1985.

\section{NOTAS DE FIM}

1. Segundo Freud, "a melancolia se caracteriza, em termos psíquicos, por um abatimento doloroso, uma cessação do interesse pelo mundo exterior, perda da capacidade de amar, inibição de toda atividade e diminuição da autoestima, que se expressa em recriminações e ofensas à própria pessoa e pode chegar a uma delirante expectativa de punição." (FREUD, 2000, p. 172)

2. Para a análise de outros aspectos da experiência desse processo de modernização em Buenos Aires, ver os demais trabalhos apresentados sob a organização de Romero e Romero (2000), Lobato (2000) e Gutman e Reese (1999).

3. Sobre o tema da censura ao tango, ver Fraga (2006), Vardaro (2007) e Martínez Moirón (1971). Abordei o tema também, de forma mais alentada do que aqui vai, em minha tese de doutorado (PEREIRA, 2012a).

4. Para outros estudos biográficos e análises da poética de Enrique Santos Discépolo, ver Ferrer e Sierra (2004), Galasso (2004), Rivera (1973), Pellettieri (1976), Conde (2003).

5. Observo que termos análogos aparecem nos títulos de tangos que Discépolo compôs no período: Desencanto (1937), Condena (1938), Tormenta (1939), Martirio (1940), Infamia (1941), e ainda Canción Desesperada (1944), mas apenas Tormenta lembra o protesto de Cambalache, maldizendo a 
injustiça e a desonestidade: "si la vida es el infierno / y el honrao vive entre lágrimas". Nos demais, o tema é a desilusão amorosa, não menos afeita à "estética do desencanto", mas abordando-a por uma lente distanciada do cotidiano político.

6. Outras abordagens críticas ao texto de Scalabrini Ortiz também salientam sua vinculação com as inflexões que antecedem a crise de 1929-30. Para Beatriz Sarlo, "sin las vanguardias de la década del veinte, esta escritura hubiera sido imposible” (SARLO, 2007, p. 215). Alejandro Cattaruzza e Fernando Rodríguez, prefaciando uma edição do ensaio, confirmam sua relação com as vanguardas dos anos 20, pelo antipositivismo e espiritualismo em que se baseia (CATTARUZZA e RODRÍGUEZ, 2007, p. 13).

7. Seguramente, o diálogo com Ortega y Gasset se faz sentir também aí. Oscar Terán (2008, p. 197) observa que o filósofo espanhol incomodou-se com o anacronismo da vida intelectual argentina, ainda muito marcada pelo positivismo e vemos Scalabrini Ortiz reagir claramente a esse mesmo positivismo.

8. Sobre essa visão de Ortega y Gasset sobre o papel dos intelectuais na sociedade, ver também Warley, 1985, p. 53.

9. Vale lembrar que Corrientes y Esmeralda é também o título de um poema de Celedonio Flores, escrito em 1922, e musicado em 1933 por Francisco Pracánico, dando origem a um clássico do repertório tanguero. O poema é uma homenagem àquela esquina de Buenos Aires e sua vizinhança, onde orquestras de tango tocavam para um público masculino em cafés como o Royal Keller, justo na esquina mencionada, e frequentado pelo próprio Scalabrini, célebre pelas tertúlias literárias e palco das primeiras lutas de boxe realizadas na cidade (SAÍTTA, 2007). Tanto Flores quanto Scalabrini lutaram boxe na juventude, e o primeiro verso do tango faz alusão à luta - "amainaron guapos junto a tus ochavas / cuando un cajetilla los calzó de cross" - marcando a derrota dos guapos das orillas pela nova luta praticada pelos cajetillas do centro.

10. Cattaruzza e Rodríguez observam que a interpretação dos anos 60 sustentava que o autor havia analisado o argentino da "década infame" numa localização temporal "ficticia, ya que el libro había aparecido en 1931", mas "contribuía a transformar el ensayo de Scalabrini en una consideración sobre la situación de aquellos hombres, que esperaban en soledad durante un período - la llamada Década Infame - al que el peronismo habría puesto fin" (CATTARUZZA e RODRÍGUEZ, 2007, p. 10). Assim, o ensaio seria convertido em peça de uma "batalla cultural que se libraba a mediados de la década de 1960, cuyos actores eran los muy heterogéneos conjuntos divididos por el apoyo o la crítica al movimiento liderado por Perón" (Idem).

11. Apresento uma análise mais aprofundada do tema em minha tese de doutorado (PEREIRA, 2012a). Ver também Pereira, $2014 b$.

\section{RESUMOS}

Em sua análise da lírica de Baudelaire, Walter Benjamin aborda a cidade, a multidão, a melancolia e o choque traumático resultante do impacto da modernidade sobre a sensibilidade dos intelectuais e do público leitor oitocentistas. A experiência moderna e a circulação de ideias aproxima Paris e Buenos Aires, e os mesmos temas são recriados nessa nova manifestação lírica que é o tango-canción. Neste trabalho, analiso como alguns poetas do tango reagem à modernidade e elaboram uma identidade social em torno da melancolia e dos mecanismos e espaços de sociabilidade, em consideração aos representações sobre o "homem argentino" presentes nos escritos de Ortega y Gasset e Scalabrini Ortiz.

Dans son analyse de Baudelaire, Walter Benjamin traite de la cité, de la foule, de la mélancolie et du choc traumatique résultant de l'impact de la modernité sur la sensibilité des intellectuels et du public lecteur du XIXe siècle. L'expérience moderne et la circulation des idées ont depuis 
rapproché Paris et Buenos Aires, et les mêmes thèmes sont recréés dans cette nouvelle manifestation lyrique qu'on appelle le "tango-canción". Dans ce travail, j'analyse comment quelques poètes du tango ont réagi à la modernité et ont créé une identité sociale autour de la mélancolie, de ses mécanismes et espaces de sociabilités, en prenant appui sur les représentations de l'homme argentin présents dans les écrits de Ortega y Gasset y de Scalabrini Ortiz.

\section{ÍNDICE}

Mots-clés: Tango et modernité, Solitude et Mélancolie, Buenos Aires, Intellectuels.

Palavras-chave: Tango e Modernidade, Solidão e Melancolia, Buenos Aires, Intelectuais

\section{AUTOR}

\section{AVELINO ROMERO PEREIRA}

Universidade Federal do Estado do Rio de Janeiro (UNIRIO)

Professor de História da Música

romeroavelino@yahoo.com.br 